\title{
Detection and Antibiogram of Escherichia coli 0157 from Feral and Cultured Tilapia (Oreochromis niloticus) in Ibadan, Nigeria
}

\author{
Seto Charles Ogunleye ${ }^{1 *}$, Ishola Olayinka Olabisi² ${ }^{2}$ Okunlade Olayemi Akinsola $^{3}$, Adedeji Olufemi Bolarinwa ${ }^{4}$, \\ Okocha Reuben ${ }^{5}$ \\ ${ }^{1,2,3}$ Department of Veterinary Public Health and Preventive Medicine University of Ibadan, Nigeria. \\ ${ }^{I}$ Department of Comparative Biomedical Sciences, College of Veterinary Medicine, Mississippi State University, USA \\ ${ }^{4}$ Landmark University SDG 14 (Life below Water), P. M. B. 1001, Omu-Aran, Kwara State, Nigeria \\ ${ }^{5}$ Department of Agriculture, Landmark University, P. M. B. 1001, Omu-Aran, Kwara State, Nigeria \\ * Corresponding Author
}

\begin{abstract}
One of the most important Escherichia coli strains known is $E$. coli 0157 and is known to cause important human diseases including food poisoning, gastroenteritis, septic shock, etc. Its isolation from food materials and resistance to antibiotics are of increasingglobal-public health concerns. This study investigated prevalence and antibiogram of $E$. coli 0157 from Oreochromis niloticus $(O$. niloticus)..A total of 156 samples consisting of gills, intestines and skins were collected from 52 O. niloticus obtained from $\operatorname{Egbeda}(A)$, Ido(B), Ibadan-North East(C) and Ibadan North-West(D) Local Government Areas of Ibadan for bacteriological analysis. $E$. coli 0157 Isolation and identification were performed using the EU, 2017 Reference Laboratory standards forenterobacteracea isolation and characterization, and antibiogram of $E$. coli 0157 was performed using standard methods.In this study, the overall prevalence of $E$. coli 0157 obtained from $O$. niloticus was $62.5 \%$ with prevalence of $62.5 \%, 37.5 \%$ and $87.5 \%$ from gill, intestine, and skin, respectively, while the overall location prevalence were observed as: $65.4 \%$ (A), $65.4 \%$ (B), $66.7 \%$ (C) and $50.0 \%$ (D). Isolates exhibited resistance patterns comprising: 100.0\%(Ceftazidime, Cefuroxime and Meropenem),
\end{abstract} 91.7\%(Cefotaxime),83.3\%(Tetracycline),

41.5\%(Cotrimoxazole),75.0\%(Ceftriaxone), $16.7 \%$ (Gentamycin), 8.3\%(Ciprofloxacin), and $0.0 \%$ (Amikacin, Chloramphenicol). Multi-drug resistance patterns were observed as: CRX- CFZMEM-(100\%), CRX-CTR-CTX-CFZ-MEM-(83.3\%), CRXCTR-CTX-CFZ-MEM-TET(66.7\%), CRX-CTR-CTX-CFZMEM-TET-COT(58.3\%) and CRX-CTR-CTX-CFZ-MEM-TETCOT-GEN $(8.3 \%)$. Prevalence of $E$. coli 0157 in $O$. niloticus obtained from Ibadan andits multi-drug resistance patterns observed in this studyindicate aquaticcontaminations, and abuse of antibiotics, portendingfood safety and public health threats.

Keywords: Prevalence, Escherichia coli 0157, Antibiogram, and Oreochromis niloticus.

\section{INTRODUCTION}

A quaculture industry has recently become one of the fastest growing sources of animal protein with global acceptability cutting across all socio-demography and religion sects (Adebayo-Tayoet al., 2010, FAO, 2018). Nigeria, like many other nations of the world, is one of the producers of aquatic products which have favourably competed with meat from other food animals (Adebayo-Adetayoet al., 2010). The acceptance of fish can be attributed toits importance in maintenance of health and wellbeing, distinctively, for unique taste, flavour and good texture(Adebayo-Adetayo et al., 2010). Oreochromis niloticus commonly known as Tilapia,belonging to the tilapiine group has become the most cultured and acceptable fish in many parts of the world (José et al., 2017). It has gained worldwide acceptance exemplified by minute amounts of saturated fat, calories, carbohydrates, and sodium, as well as micronutrients, phosphorus, niacin, selenium and potassium. (Robin et al., 2006; Ayanda et $a l ., 2018)$. Despite the enormous health and dietary benefits of tilapia, it is a potential source of food-borne infections to human consumers and/or handlers at every stage of production (Norma et al., 2018). Although, many of the microbes associatedwithfish are informed by theaquaticenvironmentin which they are produced, majority of them are potential spoilers, and potential health threat to human upon consumption of contaminatedfish and/orfish products (Ibrahim et al., 2014). Bacteria associated with fish are broadly classified as non-pathogenic bacteria (e.g. Clostridium botulinum, Salmonella spp, Listeria monocytogenes, Staphylococcus aureus, Shigella spp. and Escherichia coli (Vasemägi et al., 2017; Fernandes et al., 2018), and pathogenic bacteria (e.g.Vibrio spp., Vibrio parahaemolyticus, Aeromonas, and Yersinia. (Elhadi et al., 2016).

Escherichia coli (E. coli) belongs to the family Enterobacteriaceae. It is a rod-shaped, Gram-negative bacterium which is commonly found in the lower intestine of most of the warm-blooded organisms (Jang, 2017). It has been found to be important pathogenic bacteria associated with freshly harvested or processed fish and are of significant global-public health problem, and a leading cause of most bacterial food-borne illnesses (Ibrahim et al., 2014; WHO, 2019) with different disease syndromes including septic shock, meningitis, or urinary tract infections, gastroenteritis, bacteraemia, and typhoid fever and in severe 
cases, death in humans (Meiyarasi et. al., 2017). Among the $E$. coli species, the enterohemorrhagic E. coli (EHEC) is classified as a pathogenic strain because it produces Shiga toxins (Stxs), responsible for causing hemorrhagic colitis (HC) and Hemolytic Uremic Syndrome (HUS) in immunocompetent humans. Human diseases have been associated with the O26:H11, O91:H21, O111:H8, O157:NM, and O157 (Melton-Celsa, 1996; Paton, 1997) serotypes. Escherichia coliO157 has been identified as the most important serotype frequently associated with human infections. According to the WHO, 2019, E. coli 0157 has been indicated as a causalagent for an estimate of 3,600 human hospitalizations in the US.

Consumption of contaminated food and water are the most frequent route of transmission while spread can also occur directly from person to person and from animal to person (Alam et al., 2004). Recently, airborne transmission has been found to be a new route of transmission through contaminated buildings that contains animal exhibit (Varma et al., 2003). The occurrence of this pathogen in fish is commonly related to its breeding, industrialization of environment andunhygienic practices(Fernandes et al., 2018). Fish contamination occurs through indiscriminate deposition of excreta and other wastes and unhygienic handling by human healthy carriers (Adedeji et al., 2011and Fuhrimann et al., 2015). Several studies have described the epidemiology and the prevalence of E. coli in fishranging between 4-90\% (Adedeji et al., 2011; Rafael et al., 2014; Tiamiyu et al., 2015 and Kikomeko et al., 2016). These therefore, suggestthat microbiological standards for fish processing and marketing be established to ensureabsence of $E$. coli in foods in compliance with World Health Organization (WHO).

Antibiotic resistance and Multi Drug Resistance (MDR)global menace have continued to be on the rise with developing countries being worst affected; since most of these countries exhibit practices and attitudes that promote the development and spread of resistant microorganisms. This can be partly associated to the antibiotic prescriptions practices in many hospitals without confirmatory appraisal of the evidence of infections as well as identification of the causal agents (Prescott et al., 1999). Furthermore, unaffordable laboratory tests and consultation fees, also have culminated in the present day practices of administration/prescription of broad spectrum antibiotics. This however results often to exposure to more bacteria, with resultant risks of dangerous side effects, super infections and the development of drug resistant mutants. Antibiotic therapy scheme for most E. coli infections includes third generation cephalosporin antibiotics, quinolones and macrolides. However, resistance and MDR to these drugs have been on the increase (Tiamiyu et al., 2015 and Kikomeko et al., 2016). Antimicrobial resistance (AMR) and the emergence of multiple drug resistant to E. coli (MDR) has become global public health concernrepresenting an increase in the severity of foodborne disease, leading to increased morbidity and/or mortalities of humans (Rafael et al., 2014; Kikomeko et al., 2016). Understanding the main risk factors and how to reduce them is therefore essential for developing best management practice to safeguard public health. Therefore, this study was designed with a view to assess the presence of E. coli $\mathrm{O} 157$ in O. niloticus collected from different locations inIbadan, Nigeria.

\section{MATERIALS AND METHODS}

\section{Study Area}

Ibadan, Oyo state, Nigeria the largest city in West Africa, and the second largest in Africa, has land size of about $240 \mathrm{~km}^{2}$, situated at an average height of $200 \mathrm{~m}$ above sea level, surrounded by secondary rainforest and savanna, and drained by three major river basins (Ogunpa, Ona and Ogbere). It is located on geographic grid reference longitude $3^{\circ} 5 \mathrm{E}$, latitude $7^{\circ} 20 \mathrm{~N}$ (Filani, 1994). It is an important region where intensive aquaculture and fishery activities form a central pivot.

\section{Sampling Method and Sample Collection}

Egbeda (A), Ibadan North West (B), Ido (C) and Ibadan North East (D) Local Government Areas (LGAs) in Ibadan were purposively selected based on the availability of Oreochromis niloticus. A total of fifty-two (52) apparently healthy (average weight $120.00 \pm 0.00 \mathrm{gm}$ ) live tilapia comprising 16 each from the feral $(\mathrm{A}$ and $\mathrm{B})$ and 10 each from cultured farms $(\mathrm{C}$ and $\mathrm{D})$ were collected between July and August, 2019. Sampled tilapia were transported to the Food and Milk Hygiene Laboratory of the Department of Veterinary Public Health and Preventive Medicine, University of Ibadan for bacteriological analysis. On arrival at the laboratory, fish were stored briefly and were properly identified (Chapman, 1992, FAO, 2016) and organs of interest were aseptically harvested using scalpel. $1 \mathrm{gm}$ of samples of gills, intestine and skin were collected and aseptically macerated with peptone water. A total of 156 samples consisting 52 of gill, intestine and skin samples were collected from the 52 Oreochromis niloticus for bacteriological analysis. Microbiological Standards and Guidelines by European Union Reference Laboratory (EU, 2017) for isolation and characterization of E. coli 0157 were used during the research work. The study was approved by the Animal Care and Use Research Ethics (ACUREC), University of Ibadan, Nigeria with approval number: UIACUREC/19/0079.

\section{Isolation and Identification of Escherichia coli 0157}

Isolation ofEscherichia coli 0157was carried out according to the European Union Reference Laboratory (EU, 2017) for isolation and characterization of E. coli O157. Non-selective pre-enrichment was performed by aseptically harvesting $1 \mathrm{gm}$ of tissue sample, and then homogenised in $9 \mathrm{mls}$ buffered peptone water $(\mathrm{LabM} \circledast, \mathrm{UK})$ in a test-tube to give a dilution of 1:10. Test-tubes were corked properly, labeled and incubated overnight at $37^{\circ} \mathrm{C}$. A $10 \mu \mathrm{l}$ wire loop was used to pick a loop-full volume from the pre-enrichment broth and plated MacConkey Agar (LabM, UK) for Selective agar plating, and incubated at $37^{\circ} \mathrm{C}$ overnight. Colonies which 
showedpinkish morphology suspected to be E. coli were subcultivated unto Sorbitol MacConkey Agar-(SMAC) $\left(\right.$ Oxoid $\left.^{\mathrm{R}}\right)$ and incubated overnight at $37^{\circ} \mathrm{C}$. The colonies appearing colourless on SMAC were selected as E. coli O157, and was followed by storage of pure cultures onto nutrient agar slants, incubated at $37^{\circ} \mathrm{c}$ overnight and stored in the fridge at $2^{0} \mathrm{C}-8^{0} \mathrm{C}$

\section{MORPHOLOGICAL AND BIOCHEMICAL TESTS}

Morphological characteristics of isolates were performed through Gram staining. Biochemical characterization of isolates was performed by using Sugar fermentation tests, Catalase, Indole and Triple Sugar Iron agar(TSI) and then Incubated at $37^{\circ} \mathrm{C}$ overnight.

\section{Antibiotic Susceptibility Test}

The antimicrobial susceptibility test was carried out using the agar disk diffusion method as described by Bauer et al. (1966) and Clinical and Laboratory Standards Institute (CLSI) 2017 was used for the reading and interpretation of the zone of inhibition. Antibiotic sensitivity and resistance patterns of isolated E. coli $O 157$ were performed against 12 commonly used antibiotics belonging to different groups, using commercially available antibiotic discs (Biomark Lab®), containing antibiotics at different micrograms; Amikacin (AMK, 30 $\mu \mathrm{g}$ ), Cefotaxime (CTX, 30 $\mu \mathrm{g}$ ), Ceftazidime (CPZ, $30 \mu \mathrm{g}$, Ceftriaxone (CTR, 30 $\mu \mathrm{g}$ ), Cefuroxime (CRX, 30 $\mu \mathrm{g}$ ), Chloramphenicol (CHL, 10 $\mu \mathrm{g}$ ), Ciprofloxacin (CIP, 5 $\mu \mathrm{g}$ ), Cotrimoxazole (COT, 25 $\mu \mathrm{g}$ ), Gentamicin (GEN, 10 $\mu \mathrm{g}$ ), Meropenem (MEM, 10 $\mu \mathrm{g}$ ), Tetracycline (TET, 10 $\mu \mathrm{g}$ ).

The inoculated plates containing the antibiotic discs were examined after 24hours of incubation at $37^{\circ} \mathrm{C}$ overnight. Diameters of the zones of inhibition were measured to the nearest millimetre, using ruler, which was held on the back of the inverted Petri plate. The Petri plate was held a few inches above a black, non-reflecting background and zones are measured in millimetre $(\mathrm{mm})$ from the upper surface of the agar illuminated with reflected light, with the cover removed (EUCAST, 2015).

\section{Data analysis}

Data were analyzed using descriptive statistics and ChiSquare to test association between variables the prevalence among the groups.

\section{RESULTS}

\section{Identification of Escherichia coli 0157}

From the one-hundred and fifty six (156) samples consisting 52 each of gill, intestine and skin samples collected from the 52 Oreochromis niloticus, E. coli 0157 was isolated from a total of ninety-nine (99) samples. This represents an overall prevalence of $63.0 \%$. The positive isolates comprised of thirty-three (33) gill, twenty (20) intestine and forty-six (46) skin samples representing $62.5 \%, 37.5 \%$ and $87.5 \%$, respectively. The isolates based on location comprised 32(A), 32(B), 20(C), and 15(C). These assumedoverall location prevalence were observed to be $65.4 \%, 65.4 \%, 66.7 \%$ and $50.0 \%$ for locations A, B, C and D, respectively.

Based on the locations, prevalence; $50.0 \%, 50.0 \%$ and $100.0 \%$ were observed for the gills, intestines and skin, respectively from the Location A(32: Gills -8; intestines-8 and skin-16); $100.0 \%, 0.0 \%$ and $100.0 \%$ were observed for the gills, intestines and skin, respectively from the Location B(32: gills -16; intestines-0 and skin-16); 50.0\%, 50.0\% and $100.0 \%$ were observed for the Gills, intestines and skin, respectively from the Location C(20: gills -5; intestines-5 and skin-10); and $50.0 \%, 50.0 \%$ and $50.0 \%$ were observed for the Gills, intestines and Skin, respectively from the Location $\mathrm{D}(15$ : gills -5 ;intestines-5 and skin-5).

A significant difference $(\mathrm{p}<0.05)$ was observed between the isolates obtained from the three (3) organs while. Isolates obtained from the four (4) locations showed no significant difference $(p>0.05)$.

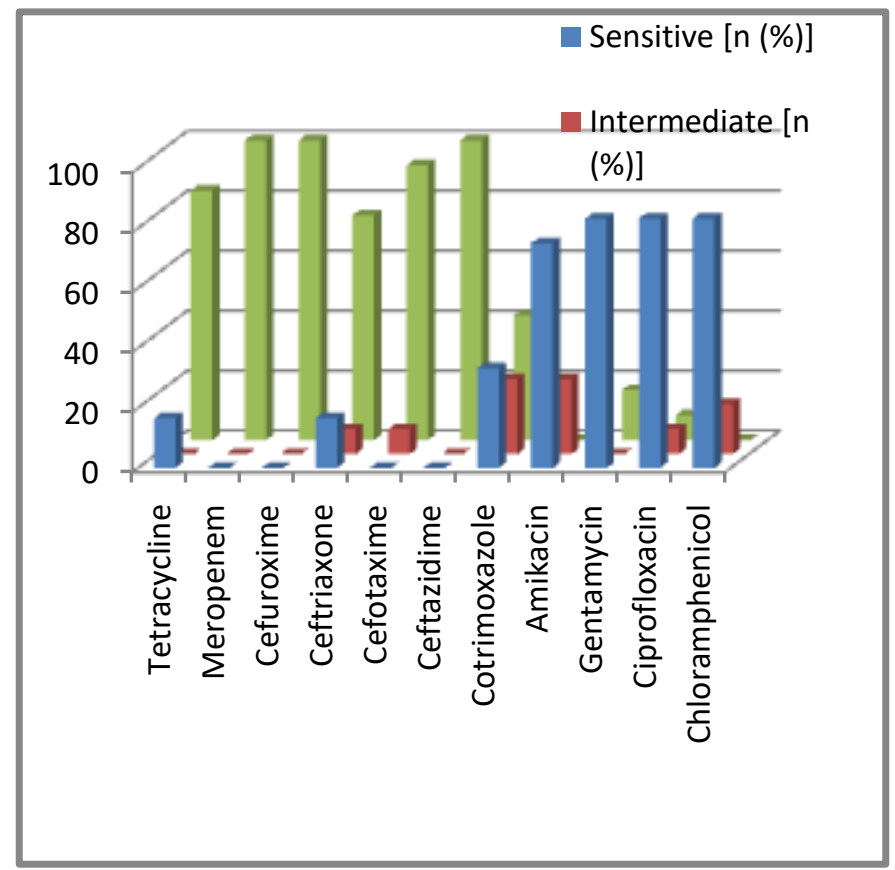

Fig 1: Histogram showing the resistance pattern of isolated E. coli 0157 to commonly used antibiotics

Table 1: Multi-Drug Resistance Pattern for Escherichia coli 0157

\begin{tabular}{|c|c|}
\hline Antibiotics & Number of Resistant Isolates (\%) \\
\hline CRX-CFZ-MEM & 100.0 \\
\hline CRX-CTR-CTX-CFZ-MEM & 83.3 \\
\hline CRX-CTR-CTX-CFZ-MEM-TET & 66.7 \\
\hline $\begin{array}{c}\text { CRX-CTR-CTX-CFZ-MEM-TET- } \\
\text { COT }\end{array}$ & 58.3 \\
\hline $\begin{array}{c}\text { CRX-CTR-CTX-CFZ-MEM-TET- } \\
\text { COT-GEN }\end{array}$ & 8.3 \\
\hline
\end{tabular}

Abbreviations: Amikacin (AMK, 30 $\mu$ ), Cefotaxime (CTX, $30 \mu \mathrm{g}$ ), Ceftazidime (CPZ, 30 $\mu \mathrm{g}$, Ceftriaxone (CTR, 30 $\mu \mathrm{g}$ ), Cefuroxime (CRX, 30 $\mu \mathrm{g}$ ), Chloramphenicol (CHL, 10 $\mu \mathrm{g}$ ), 


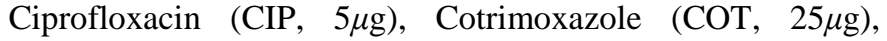

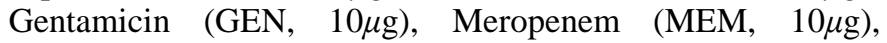
Tetracyclin (TET, $10 \mu \mathrm{g})$.

Antibiotics belonging to different families were tested with each of the isolates. The different diameters obtained for each isolates were compared with the CLSI and EUCAST standards to determine whether they are resistant, intermediate or sensitive to each of the antibiotics.Escherichia coli 0157 isolates tested showed highest resistance (100\%) to ceftazidime (CPZ), cefuroxime (CRX) and meropenem (mem) while highest susceptibility (83.3\%)was observed forciprofloxacin (CIP), chloramphenicol (CHL) and gentamycin $(G E N)$ as shown in Fig 1. Different levels of Multi-Drug Resistance (MDR) patterns were observed with $100 \%$ to the combination of CRX, CPZ, and MEM and least MDR of $8.3 \%$ to CRX-CTR-CTX-CFZ-MEM-TET-COTGEN(Table 1).

\section{DISCUSSION}

Observed prevalence of Escherichia coli 0157in this study could be due to environmental factors and human activities such as defecation and refuse deposition in water bodies that play roles in contamination of water bodies which were observed at sampling locations. These observations are similar to those of Adedeji et al., 2011; further affirming tilapia as a possible source of E. coliO157 to consumers and the consequential possible foodborne illness to consumers. Escherichia coli 0157isolated from O. niloticus (tilapia) in this study was observed to be $63.0 \%$ by conventional bacteriological. This report is similar to reports of Ibemenugaet al., 2014 and Danbaet al., 2014 who both reported prevalence of $57.6 \%$ and $54.7 \%$, respectively. However, the prevalence in this study is higher than the reported prevalence by Adebayo-Tayoet al., 2012 (20.0\%); andTiamiyuet al., 2011 (24.0\%). Pathogenic E. colican cause foodborne disease, ranging from mild enteritis to serious illness and death. E. coli causes diarrhea, urinary tract and kidney infections and peritonitis septiceamia (Meiyarasi et. al., 2017). Where animal manure is used as pond fertilizers, there is a risk that pathogenic strains of E. coli may be present in pond water leading to the occurrence of waterborne human infection caused by $E$. coli 0157 ; hence a potential risk to public health where bovine manure is used as pond fertilizer (WHO, 1997; Rafael et al., 2014; Tiamiyuet al., 2015 and Kikomeko et al., 2016).The isolation of E. coli 0157 from fish samples in this study is worrisome because of their potential in causing ill-health in human upon consumption. These pathogens might have been introduced into the production systems through indiscriminate deposition of excreta and other wastes as well as through unhygienic handling by human healthy carriers as affirmed by Tiamiyuet al., 2011 and Fuhrimannet al., 2015.Fish as an important source of animal protein for human diet (Ayanda et al.,2018) are susceptible to variety of bacteria through human activities, unhygienic practices, industrialization etc (Adedeji et al., 2012), as well as subsequent contamination of fish and fish products during storage and improper handling or cooking, thereby portending public health hazards to humans(Seelet al., 2016)

Resistance of bacteria to antimicrobial agents and the MDR are a reflection of misuse or abuse of these antibiotics in the sampled fish, as well as indiscriminate use and disposal of antibiotics in the environment, posing health hazards to humans (Okpoet al., 2016). A 100\% resistance by E. coli O157 isolated from $O$. niloticus (tilapia) in this study was observed for Ceftazidime, Meropenem and Cefuroxime and susceptibility to Ciprofloxacin, Chloramphenicol and Gentamicin were observed in this study. The observed sensitivity of $E$. coli $\mathrm{O} 157$ to Gentamicin and resistance to Cefuroxime, Cotrimoxazole and Tetracycline are similar to reports of Adedeji et al., 2011; Tiamiyuet al., 2015 and Kikomeko et al., 2016 who all reported E. coli O157 to be sensitive to Gentamicin and resistant to Cefuroxime, Cotrimoxazole and Tetracycline. However, this report contrasts the report of the resistance of E. coli to Ciprofloxacin and Chloramphenicol by Adedeji et al., 2011. The resistance and susceptibility profile observed from this study are also partly similar to the findings of Adedeji et al., 2012; Rafael et al., 2014; Musefiu and Olasunkanmi, 2015 and Kikomeko et al., 2016.The Antibiotic sensitivity tests conducted on the isolated $E$. coli obtained from $O$. niloticusin this study revealed multiple drug resistance of E. coli to 3-8 antibiotics especially to those commonly used in fish farms such as cotrimoxazole and tetracycline. These observations are similar to reports of Rafael et al., 2014 and Tiamiyuet al., 2015.The observed MDR in this study evidences this pathogen as multi resistant bacteriumin nature, representing a potential threat to human and public health. MDR is a global public health problem associated with outbreak of major global epidemics (Crump et al., 2015). This report therefore confirms E. coli resistance to antibiotics evidencing transfer risks of resistant bacteria and genes to human through consumption of aquaculture products (Kikomekoet al., 2016). Coincidentally, the resisted antibiotics are found to be those categories and types commonly used for treatment of various ailments in humans. This rather unfortunate incidence therefore supports the theories of antibiotics' introduction into the aquatic ecosystems from humans as described by Rafael $e t$ al., 2014 and further reinforced by the reports of Owino, 2014 and Fuhrimannet al., 2015. The observed antibiotic resistance and MDR in this study therefore support hypothesis about the rapidly increasing menaces of AMR and MDR globally and a global public health problem associated with outbreak of major global epidemics (Levy et al., 2001 and Crump et al., 2015) and resultant drug side effects, super infections and development of drug resistant genes and mutants genes (Kikomekoet al., 2016).

\section{CONCLUSION}

1. This study revealed thattilapia obtained from Ibadan are contaminated with Escherichia coli 0157 which is a pathogen of public health importance, hence, could be transmitted to humans upon consumption. 
2. This study also elucidated the multi-drug resistant characteristics of E. coli0157 isolates fromtilapia obtained from Ibadan; this could lead to transfer of resistant bacteria and genes to human from handling and/or consumption of contaminated fish and from the environment.

\section{RECOMMENDATIONS}

- This study confirmed the occurrence of E. coli in the study areas and since thispathogen is of public health importance, awareness should be created among fish farmers and stakeholders on possible health hazards accompanying handling and/or consumption of fresh and undercooked fish.

- A comprehensive epidemiological study of E. coli in Nigeria is highly recommended, and systems for monitoring contamination levels of other zoonotic pathogens should be instituted into the aquatic value chain.

- Further researches and studies of aquatic animal health and zoonosis should be adapted and employed as part of the tools for controlling diseases of public health importance.

- Regulatory policies and standard operating practices for hygienic practices in the fishing and aquatic environments, controlled human activities, fishing procedures and handling of fish should be instituted and be followed by fishers and farmers to avoid disease outbreaks.

\section{CONFLICTS OF INTEREST}

Authors have no conflict of interest.

\section{ACKNOWLEDGMENT}

We wish to appreciate Dr G.O Oladosu, thefish farmers, and the Department of Veterinary Public Health and Preventive Medicine, University of Ibadan, Nigeria.

\section{REFERENCES}

[1] Adebayo-Tayo, B.C., Odu, N.N., Anyamele, L.M., Igwiloh, N.J.P.N. \&Okonko, I.O. (2012). Microbial Quality of Frozen Fish Sold In Uyo Metropolis. Nature and Science, 10(3): 71-77.

[2] Adedeji O. B., Tiamiyu A. M., and Emikpe B. O. (2011). The Antibiotic Resistant Patterns of Bacterial Flora of Fish from Different Aquatic Environments from Ibadan, South-west Nigeria. Journal of AdvancedEnvironmentalBiology, 5(8).: 2039-2047.

[3] Adedeji, O.B, Okerentugba, P.O, Innocent, D.E, Adiele, H.C \&Okonko, I.O. (2012). Benefits, Public Health Hazards and Risks Associated with fish Consumption. New York Science Journal; 5 (9):33-61.

[4] Alam, M. \& Zurek, L. (2004). "Association of Escherichia coli O157 with houseflies on a cattle farm". Journal of Applied Environmental Microbiology, 70 (12): 7578-80. doi:10.1128/AEM.70.12.7578-7580.2004.

[5] Ayanda, I. O., Dedeke, G.A., Ekhator, U. I., \&Etiebet, A.K (2018). Proximate Composition and Heavy Metal Analysis of Three Aquatic Foods in Makoko River, Lagos, Nigeria. Journal of food quality. 2362843; 6.doi:10.1155/2018/2362843Chapman FA. Culture of hybrid tilapia: a reference profile. Circular 1051,
Department of Fisheries and Aquatic Sciences, Florida Cooperative Extension Service, Institute of Food and Agricultural Sciences, University ofFlorida, 1992; pp.8

[6] Clinical and Laboratory Standards Institute. Performance Standards for Antimicrobial Susceptibility Testing 2017; M02-A12, M07-A10, and M11-A8. 27th Edn, 282.

[7] Cosby, D., Nelson, C., Mark, H., Jeanna, W., Richard, B. \& Paula, F.C. (2015). Salmonella and antimicrobial resistance in broilers: A review. The Journal of Applied Poultry Research. 24. doi:10.3382/japr/pfv038.

[8] Crump, J. A., \&Heyderman, R. S. A. (2015). Perspective on Invasive Salmonella Disease in Africa. Clinical Infectious Diseases. 61(S4):S235-40. doi: 10.1093/cid/civ709.

[9] Danba, E. P., Bichi, A. H., Ishaku, S., Ahmad, Buba, M. K., Bingari, U. M., Barau S. B. W. and Fidelis, U. F. (2014). Occurrence of pathogenic Bacteria associated with Clariasgariepinus in selected Fish farms of Kumbotso local Government area of Kano state, Nigeria. Bajopas 7 (2): 145-49. 46. doi: $10.4314 /$ bajopas.v7i2.25

[10] Elhadi, N., Aljeldah, M. and Aljindan, R. (2016). Microbiological contamination of imported frozen fish marketed in Eastern Province of Saudi Arabia. International Food Research Journal, 23(6).: 2723-2731.

[11] FAO 2016. The State of World Fisheries and Aquaculture 2016. Contributing to Food Security and Nutrition for All. Rome. 200 pp. Retrieved from http://www.fao.org/3/a-i5555e.pdf

[12] FAO 2018. Fisheries Technical Papers-T142. The production of fish meal and oil. Fisheries Industries Division, Food and Agriculture Organization of the United Nations, Rome, Italy. Retrieved from http://www.fao.org/DOCREP/003/X6899E/X6899 E00.HTM

[13] Filani M.O. (1994), Ibadan Region, Re-Charles Publications in Conjunction with Connell Publications, Ibadan, Nigeria

[14] Fernandes, D.V., Castro, V. S., Cunha-Neto, A. \&Figueiredo, E. E. (2018). Salmonella spp. in the fish production chain: a review. Cienc. Rural. 48(8):1-11. Doi:10.1590/0103-8478cr20180141

[15] Fuhrimann, S., Stalder, M., Winkler, M. S., Niwagaba, C. B., Babu, M., Masaba, G. \% Utzinger, J. (2015). Microbial and chemical contamination of water, sediment and soil in the Nakivubo wetland area in Kampala, Uganda. Environmental monitoring and assessment. 187, 475. doi: 10.1007/s10661-0154689

[16] Ibemenuga, K. N. \& Okeke T. E. (2014). bacteriological quality of freshwater fish caught from two natural lakes in the rainforest region of South-Eastern Nigeria. Journal of Animal research international, 11(2). 1946 - 1952

[17] Ibrahim, A. R., Lawan, F.A., Bello, H.S., Musa, A.S., Ameh, J.A. \&Ambali A.G. (2014). Occurrence and antimicrobial susceptibility profiles of Salmonella serovars from fish in Maiduguri, subSaharah, Nigeria. Egyptian Journal of Aquatic Research; 40 5963; doi:10.1016/j.ejar.2014.01.003

[18] ICMSF. Microorganisms in Foods, Sampling for Microbiological Analysis: Principles and Specific Applications 1986; 2nd Edn, University of Toronto Press, Toronto.

[19] ICMSF., (1986). Microorganisms in Foods, Sampling for Microbiological Analysis: Principles and Specific Applications. Second edition, University of Toronto Press, Toronto.

[20] ICMSF., (2005). Microorganisms in Foods, Sampling for Microbiological Analysis: Principles and Specific Applications. Second edition, University of Toronto Press, Toronto

[21] ICMSF., 2005. Microorganisms in Foods, Sampling for Microbiological Analysis: Principles and Specific Applications. 2nd Edn, University of Toronto Press, Toronto

[22] Jang, J., Hur, H.-G., Sadowsky, M.J., Byappanahalli, M.N., Yan, T. \& Ishii, S. (2017). Environmental Escherichia coli: ecology and public health implications - a review. Journal of applied microbiology. 123(3):570-581. doi:10.1111/jam.13468

[23] Jarvis, N.A., O’Bryan, C.A., Dawoud, T.M., Park, S.H., Kwon, Y.M., Crandall, P.G. \&Ricke, S.C. (2016). An Overview of Salmonella Thermal Destruction during Food Processing and 
Preparation. Food Control, 68, 280-290. doi:10.1016/j.foodcont.2016.04.006

[24] José, A. V., Sylvia, P. D., Julio, A. C., Magdalena, de J. U., María del, C.C., Ignacio, O. \& María, E. B. (2018). Microbiological Analysis Of Tilapia And Water In Aquaculture Farms From Sinaloa; Microbiological analysis of tilapia BIOtecnia XX (1).: 20-26.doi: 10.18633/biotecnia.v20i1.525

[25] Kikomeko H, Wamala S.P. \&Mugimba K.K. (2016). Antimicrobial resistance of Escherichia coli found in intestinal tract of Oreochromis niloticus. Uganda Journal of Agricultural Sciences, 17 (2): 157 - 164. doi:10.4314/ujas.v17i2.3

[26] Meiyarasi, T. M., Monika, B. \&Shravanthika, M. (2017). Isolation and PCR Amplification of E. coli from Freshwater Fish (Cirrhinus cirrhosis). and its PCR Amplification of SHV Gene R. International Journal of Current Microbiology and Applied Sciences, 6(4): 2467-2476. doi:10.20546/ijcmas.2017.604.288

[27] Melton-Celsa, A.R., \& O'Brien, A.D. (1996). Activation of Shigalike toxins by mouse and human intestinal mucus correlates with virulence of enterohemorrhagic Escherichia coli O91:H21 isolates in orally infected, streptomycin-treated mice. Journal of Infection and Immunity, 64: 1569-1576. doi:10.1128/IAI.64.5.15691576.1996

[28] Nguyen, D. T. A., Kanki, M., Nguyen, P., Le, H. T., Ngo, P. T. \& Tran, D. N. M. (2016). Prevalence, antibiotic resistance, and extended-spectrum and AmpC $\beta$-lactamase productivity of Salmonella isolates from raw meat and seafood samples in Ho Chi Minh City, Vietnam. International Journal of Food Microbiology. 236, 115-122. doi: 10.1016/j.ijfoodmicro.2016.07.017

[29] Okpo, N.O., Abdullahi, I.O., Whong, C.M.Z. \&Ameh, J.B. (2016). Occurrence and antibiogram of Staphylococcus aureus in dairy products consumed in parts of Kaduna State, Nigeria. Bayero Journal of Pure and Applied Sciences, 9(2): 225 - 229. doi:10.4314/bajopas.v9i2.39

[30] Owino, J.H. (2014). Determination of levels of selected antibiotics in the waters of the Nakivubo Channel, Kampala, Uganda.

[31] Paton, J.C. \& Paton, A.W. (1998). "Pathogenesis and diagnosis of Shiga toxin-producing Escherichia coli infections". Clinical Microbiology Reviews, 11 (3).: 450-479.

[32] Paudyal, N., Anihouvi, V., Hounhouigan, D., Matsheka, M., Sekwati-Monang, B., Amoa-Awua, W., Atter, A., Ackah, N., Mbugua, S., Asagbra, A., Abdelgadir, W., Nakavuma, J., Jakobsen, M. \& Fang, W. (2017). Prevalence of foodborne pathogens in food from selected African countries - A meta- analysis. International Journal of Food Microbiology. 249: 35-43; doi:10.1016/j.ijfoodmicro.2017.03.002

[33] Rafael, B., Raquel, Á., Christopher, F., Carlos, G., \& Rosa, M. R. (2014). Trypanosomatids topoisomerase re-visited. New structural findings and role in drug discovery. The International Journal for Parasitology and Drugs Resistance, 44(3): 326-337. doi:10.1016/j.ijpddr.2014.07.006

[34] Raufu I. A., Lawan F. A., Bello H. S., Musa A. S., Ameh J. A. \&Ambali A. G. (2014). Occurrence and antimicrobial susceptibility profiles of Salmonella serovars from fish in Maiduguri, sub-Saharah, Nigeria. Egyptan Journal of Aquatic Research; 40, 59-63. doi: 10.1016/j.ejar.2014.01.003

[35] Robin, J., Cravedi, J., Hillenweck, A., Deshayes, C. and Vallod, D. 2006. "Off flavor characterization and origin in French trout farming". Journal of Aquaculture. 260: 128.

[36] Seel, S. K., Kabir, S. M. L. \& Islam, M. A. (2016). Molecular detection and characterization of Escherichia coli isolated from raw milk sold in different markets of Bangladesh. 14 (2): 271-275. doi: 10.3329/bjvm.v14i2.31408

[37] Tiamiyu, A. M., Soladoye, M. O., Adegboyega, T. T. \&Adetona, M. O. (2015). Occurrence and Antibiotic Sensitivity of Bacterial Strains Isolated from Nile Tilapia, Oreochromis niloticus Obtained in Ibadan, Southwest Nigeria. Journal of Biosciences and Medicines, 3, 19-26; doi:10.4236/jbm.2015.35003

[38] Varma, J.K., Greene, K.D., Reller, M.E., DeLong, S.M., Trottier, J., Nowicki, S.F., DiOrio, M., Koch, E.M., Bannerman, T.L., York, S.T., Lambert-Fair, M.A., Wells, J.G. \& Mead, P.S. 2003. "An outbreak of Escherichia coli O157 infection following exposure to a contaminated building". Journal of the American Medical Association, $290 \quad$ (20): $2709-2712 . \quad$ doi: 10.1001/jama.290.20.2709

[39] Vasemägi, A., Visse, M. \& Kisand, V. (2017). Effect of Environmental Factors and an Emerging Parasitic Disease on Gut Microbiome of Wild Salmonid Fish. of wild salmonid fish. MSphere 2(6):e00418-17. DOI:10.1128/mSphere.00418-17

[40] World Health Organization (WHO). 2019. Interventions for the control of non -typhoidal Salmonella spp. in beef and 729 pork: meeting report and systematic review. Retrieved from http://www.who.int/iris/handle/10665/249529

[41] World Health Organization (WHO). 2019. WHO estimates of the global burden of foodborne diseases. Retrieved from https://apps. who.int//iris/bitstream/handle/10665/199350/97892415 65165_eng.pdf?sequence $=1$ 